\title{
Kontrol Sosial Masyarakat Terhadap Perilaku Menyimpang Remaja (Kasus Pacaran di Taman Syariah Kota Parepare)
}

\author{
Community Social Control Against Youth Deviant Behavior (Case of Dating in Parepare City \\ Sharia Park)
}

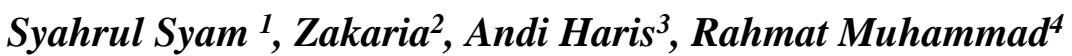 \\ ${ }^{I}$ Alumni Sosiologi Fisip Universitas Hasanuddin, Makassar, Indonesia \\ ${ }^{2}$ Dosen Sosiologi Fisip Universitas Hasanuddin, Makassar, Indonesia \\ ${ }^{3}$ Dosen Sosiologi Fisip Universitas Hasanuddin, Makassar, Indonesia \\ ${ }^{4}$ Dosen Sosiologi Fisip Universitas Hasanuddin, Makassar, Indonesia
}

\section{A R T I C L E I N F O}

\section{How to Cite:}

Syam, S., Zakaria, Haris, A., Muhammad, R. (2020).

Kontrol Sosial Masyarakat

Terhadap Perilaku

Menyimpang Remaja (Kasus

Pacaran di Taman Syariah

Kota Parepare). Hasanuddin

Journal of Sociology (HJS),

2(1), 61-72.

\section{Keywords:}

Social control, deviant behavior, dating of adolescent

Kata Kunci :

Kontrol sosial, perilaku menyimpang, kencan remaja

\begin{abstract}
A B S T RA C T
This research explains about community social control toward deviant behavior of adolescents in Parepare City, especially community social control toward adolescents who are dating in the sharia park. Qualitative research methods were used to explore and understand the meaning of the problem studies, on the basis of case study research. There were seven informants in this research, consisting of community leaders, people who lived around the park, and visitors of the sharia park. The results of the research revealed that adolescent dating behavior was still considered in the category of relative deviation. Thus, the community that controls adolescents starting from the form, nature, and control processes are very weak. This was because the community would only control optimally when the courtship of adolescents in the sharia park had entered the stage of intimacy or sexual self-disclosure. The lack of community social control was caused by lack of socialization, government oversight and a variety of existing values and norms.
\end{abstract}

\section{A B S T R A K}

Penelitian ini menjelaskan tentang kontrol sosial masyarakat terhadap perilaku menyimpang remaja di Kota Parepare, terutama kontrol sosial masyarakat terhadap remaja yang berpacaran di taman syariah. Metode penelitian kualitatif digunakan untuk mengeksplorasi dan memahami makna studi masalah, berdasarkan penelitian studi kasus. Ada tujuh informan dalam penelitian ini, yang terdiri dari tokoh masyarakat, orangorang yang tinggal di sekitar taman, dan pengunjung taman syariah. Hasil penelitian menunjukkan bahwa perilaku kencan remaja masih dianggap dalam kategori penyimpangan relatif. Dengan demikian, komunitas yang 
mengontrol remaja mulai dari bentuk, sifat, dan proses kontrol sangat lemah. Ini karena masyarakat hanya akan mengontrol secara optimal ketika pacaran remaja di taman syariah telah memasuki tahap keintiman atau pengungkapan diri seksual. Kurangnya kontrol sosial masyarakat disebabkan oleh kurangnya sosialisasi, pengawasan pemerintah dan berbagai nilai dan norma yang ada.

\section{PENDAHULUAN}

Terjadinya perilaku menyimpang diakibatkan tidak tersampaikannya nilai-nilai sosial dalam masyarakat yang mencita-citakan suatu kedamaian karena pada dasarnya masyarakat cenderung tidak mentaati nilai dan norma. Sehingga sebagai konsekuensi logisnya terjadilah suatu penyimpangan. Penyimpangan yang paling rentan terjadi yakni pada usia remaja sehingga sangatlah diperlukan adanya kontrol sosial dalam masyarakat untuk mengendalikan perilaku menyimpang remaja tersebut.

Perilaku menyimpang di kalangan remaja ini diantaranya seperti, tawuran, pemakaian obat-obatan terlarang, minum alkohol, seks bebas, serta perilaku lainnya yang bersifat dekstruktif. seks bebas yang dilakukan oleh remaja selalu diawali dengan perilaku berpacaran. Adanya perasaan saling memiliki satu sama lain ini membuat mereka lebih mudah dalam melakukan tindakan yang menyimpang.

Seperti berdasarkan survey kesehatan reproduksi remaja (SKRRI) tahun 2103, beberapa perilaku berpacaran remaja yang belum menikah saat ini sangat mengkhawatirkan. Terdapat sebanyak 29,5 persen remaja pria dan 6,2 persen remaja wanita pernah meraba atau merangsang pasangannya, sebanyak 48,1 persen remaja laki-laki dan 29 persen remaja wanita pernah berciuman bibir. Sebanyak 79,6 persen remaja pria da 71,6 persen remaja wanita pernah berpegangan tangan dengan pasangannya, melakukan seks oral 3,3 persen, berangkulan 49 persen, berpelukan 38 persen, meraba alat kelamin 7,2 persen, menggesek alat kelamin 4,5 persen dan hubungan seks 3,2 persen (Siyoto, 2017, P-3).

Sekaitan dengan gambaran di atas, kota parepare yang merupakan salah satu wilayah yang menjuluki kota santri dan kota ulama sehingga kota ini memiliki satu taman yang diberi nama taman syariah yang merupakan taman yang bernuansa penuh dengan nilai religius dengan corak agama Islam yang mencolok. Namun sayangnya taman ini justru menjadi tempat berpacaran remaja yang sudah tentu melanggar syariah.

Adanya perilaku remaja yang berpacaran ini memang menjadi perbincangan masyarakat karena dianggap ganjil dan sangatlah membuat masyarakat yang tinggal di sekitar taman resah. Pada tahun 2017 lalu taman ini kerap dijadikan sebagai tempat mesum yang hampir terjadi setiap malamnya bahkan ada warga yang telah mencoba menegur dan tidak mendapatkan respon (Mulyadi, 2017).

Hadirnya perilaku ini merupakan hasil kontrol sosial masyarakat yang tidak maksimal, beberapa masyarakat tidak melakukan kontrol sosial terhadap perilaku tersebut. Hasil observasi awal peneliti juga mendapati beberapa remaja yang berpacaran di taman syariah namun masyarakat yang berada 
dekat taman beserta pengunjung taman juga menyaksikan secara langsung tapi sayang mereka justru membiarkan perilaku tersebut. Hal inilah yang menjadi ketertarikan peneliti sehingga mengambil judul penelitian "Kontrol Sosial Masyarakat Terhadap Perilaku Menyimpang Remaja (Kasus Pacaran di Taman Syariah Kota Parepare)".

\section{TINJAUAN PUSTAKA}

\subsection{Persepsi masyarakat}

Menurut Kotler dalam (Pormawita, 2016) persepsi diartikan sebagai sudut pandang atau cara pandang terhadap objek. Persepsi ini memberi pengaruh terhadap proses pengambilan keputusan, jika persepsi seseorang itu positif terhadap suatu hal, maka pengambilan keputusan pun akan selaras dengan persepsi begitupun sebaliknya.

Hutami (2012) memberikan batasan bahwa, persepsi adalah proses seseorang dalam memilih, mengorganisasikan, dan mengiterpretasikan rangsangan- rangsangan atau stimulus yang berasal dari luar dirinya kemudian diterima menjadi sebuah gambaran yang berarti dan lengkap. Maka seseorang akan memiliki persepsi yang berbeda-beda satu dengan yang lainnya sehingga mereka akan mempersepsikan suatu peristiwa sesuai dengan gambaran yang mereka dapatkan dari luar dirinya.

Persepsi yang terbangun tentang remaja berpacaran di taman tergantung pada si pemberi makna terhadap tindakan tersebut. Adanya makin dari persepsi yang terbangun dari masyarakat akan berpengaruh pada sikap dan tindakan yang akan dilakukan terhadap remaja yang berpacaran di taman syariah.

\subsection{Kendala dan Hambatan Masyarakat}

Kendala dan hambatan yang dihadapi masyarakat dalam mengontrol tergantung dari bagaimana kontrol sosial yang dilakukan masyarakat baik lembaga fonnal maupun informal terhadap remaja yang menyimpang baik dari bentuk, proses, sifat serta efektif tidaknya kontrol sosial.

Kontrol sosial menurut Karel J. Veerger melihat pengendalian sosial sebagai titik kelanjutan dari proses sosialisasi dan berhubungan dengan cara metode yang digunakan untuk mendorong seseorang agar berperilaku selaras dengan kehendak kelompok atau masyarakat yang jika dijalankan secara efektif, perilaku individu akan konsisten dengan tipe prilaku yang diharapkan. Dalam pengendalian sosial yang akan hadir berbagai bentuk kontrol sosial terhadap remaja yang melakukan penyimpangan.

Kontrol sosial memiliki dua proses dalam pengawasan terhadap individu maupun kelompok yang menyimpang. Proses kontrol yang dilakukan ada yang internal dan eksternal atau dengan kata 
lain pengendaliannya bisa dari dalam diri individu dan juga dari luar diri individu atau kelompok tersebut. Internalisasi norma kelompok dapat berupa tuntutan atas konformitas terhadap norma dan keinginan untuk memenuhi harapan tersebut. Sedangkan reaksi sosial, berupa tekanan dari luar dalam bentuk sanksi dari pihak lain terhadap kejadian yang berkaitan dengan pelanggaran norma.

Pengendalian sosial yang dilakukan masyarakat agar terciptanya tertib sosial ada 3 yaitu pengendalian prenventif, represif dan kuratif. Pertama, pengendalian preventif adalah segala bentuk pengendalian sosial yang berupa pencegahan atas perilaku menyimpang (deviation) agar dalam kehidupan sosial tetap kondusif (konformis). Kedua, pengendalian represif adalah bentuk pengendalian sosial yang bertujuan untuk mengembalikan kekacauan sosial atau mengembalikan situasi deviasi menjadi keadaan kondusif kembali (konformis). Ketiga, pengendalian kuratif. Kuratif yaitu tindakan yang diambil setelah terjadinya tindak penyimpangan sosial.

Menurut Setiadi \& Kolip (2011), lembaga pengendalian sosial secara garis besar dibedakan menjadi dua macam yaitu lembaga pengendalian sosial formal dan lembaga nonformal. Lembaga formal misalnya kepolisian, peradilan, pendidikan, sedangkan lembaga informal seperti adat, keagamaan, tokoh masyarakat, organisasi-organisasi seperti (LSM) dan sebagainya serta lembaga penyiaran dan pemberitaan (Pers).

Efektif tidaknya kontrol sosial masyarakat terhadap remaja yang berperilaku menyimpang ditentukan seberapa efektivitas kontrol sosial menurut Setiadi \& Kolip (2015), antara lain yaitu (1) menarik tidaknya kelompok masyarakat bagi anggota masyarakat lainnya, (2) otonom tidaknya kelompok masyarakat, (3) beragam tidaknya norma-norma yang berlaku di dalam kelompok, (4) besar kecilnya dan bersifat anomie tidaknya kelompok masyarakat bersangkutan, dan (5) toleran tidaknya sikap petugas kontrol sosial terhadap pelanggaran yang terjadi.

Perilaku menyimpang dilihat dari perspektif teori kontrol adalah bahwa penyimpangan hasil dari kekosongan kontrol atau pengendalian sosial. Teori ini dibangun atas dasar pandangan bahwa setiap manusia cenderung tidak patuh pada hukum atau memiliki dorongan untuk melakukan pelanggaran hukum. Perilaku menyimpang adalah kosekuensi logis dari kegagalan seseorang menaati hukum (Setiadi \& Kolip,2015)

Menurut Desmita dalam (Jamaluddin, 2016) menjelaskan bahwa istilah remaja berasal dari bahasa latin, adolescere yang berarti tumbuh menjadi dewasa atau dalam perkembangan menjadi dewasa. Sedangkan Monks mengatakan bahwa masa remaja berlangsung antara usia 12 tahun sampai 21 tahun. Dengan pembagian 12-15 tahun adalah masa remaja awal; 15-18 tahun adalah masa remaja pertengahan; 18-21 tahun adalah masa remaja akhir. 
1. Tindakan nonconform yaitu tindakan yang tidak sesuai dengan nilai-nilai atau norma-norma yang ada.

2. Tindakan anti sosial atau sosial yaitu tindakan yang melawan kebiasaan masyarakat atau kepentingan umum.

3. Tindakan-tindakan kriminal yaitu tindakan yang nyata-nyata telah melanggar aturan-aturan hukum tertulis dan mengancam jiwa atau keselamatan orang lain.

Gunarsa mengatakan bahwa muda-mudi (remaja laki-laki dan remaja perempuan) disebut berpacaran jika terjadi pergaulan yang terbatas antara dua muda-mudi, yang berarti menunjukkan adanya suatu terkhususan di antara mereka. Terdapat empat tahapan pacaran yang dapat dituliskan sebagai berikut (Evita, 2007).

1. Tahap ketertarikan yaitu tahap ini ditandai dengan menculnya rasa ketertarikan terhadap lawan jenis. Tahap ketidakpastian

2. Tahap ketidakpastian merupakan masa peralihan dari rasa tertarik ke arah rasa tidak pasti.

3. Tahap komitmen dan ketertarikan yaitu tahap ini timbul keinginan remaja untuk berkencan dengan seseorang secara ekslusif.

4. Tahap keintiman yaitu tahap ini remaja mulai merasa lebih santai (rileks) untuk berbagi lebih mendalam dibandingkan dengan masa sebelumnya, dan merupakan kesempatan untuk lebih mengungkapkan diri.

Pacaran yang telah memasuki tahap keintiman seringkali salah mengartikannya sebagai tahap pengungkapan diri secara seksual. Hal ini menyebabkan remaja melakukan perilaku seks pranikah seperti berciuman (kissing) hingga hubungan seks (coitus).

Pacaran ditinjau dari sudut pandang agama Islam merupakan perilaku yang tidak dibenarkan karena pacaran dalam Islam itu tidaklah ada, sehingga pacaran ini merupakan suatu perilaku yang menyimpang dari agama islam. Sesuai yang telah diterangkan dalam Al-Qur'an surah A1 Isra ayat 32 yang berbunyi:

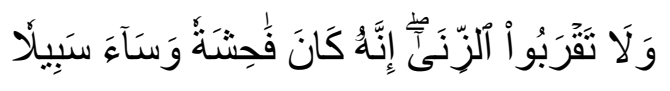

Artinya: "dan janganlah kamu mendekati zina; sesungguhnya zina itu adalah suatu perbuatan keji dan suatu jalan yang buruk".

Aktivitas yang dilarang tidak disebutkan secara gamblang mengenai aktivitas yang dilarang untuk dilakukan dalam taman, tetapi terdapat beberapa batasan secara umum. Batasan utama adalah aktivitas apapun yang dilakukan dalam taman tidak boleh tergolong aktivitas yang mempersekutukan Allah SWT.

\section{METODE}

Pendekatan kualitatif merujuk pada Denzi dan Lincol (2009), penekanan pada proses dan makna 
yang dikaji secara ketat atau belum diukur dari sisi kuantitas, jumlah, intensitas, atau frekuensinya. Tipe penelitian yang digunakan penelitian dekskriptif adalah penelitian yang berusaha mendekskripsikan suatu gejala, peristiwa, kejadian yang terjadi saat sekarang (Noor, 2014).

Penelitian ini menggunakan dasar penelitian studi kasus yang meliputi analisis mendalam dan kontekstual terhadap situasi yang mirip dalam organisasi lain, dimana sifat dan definisi masalah yang terjadi adalah serupa dengan masalah yang

Penelitan ini dilakukan pada kecamatan ujung khususnya wilayah taman syariah dan sekitarnya dengan jangka waktu penelitian selama enam bulan, yaitu mulai dari bulan Juli sampai akhir bulan Desember 2019. Lokasi penelitian ini sengaja dipilih oleh peneliti karena taman syariah yang menjadi fokus lokasi terjadinya penyimpangan ini terletak di taman Syariah

Penelitian yang dilakukan ini mewawancarai tujuh orang informan. Penarikan sampel ini mengambil tujuh informan dikarenakan sudah terjadi pengulangan informasi sehingga harus dihentikan. Jumlah informan ini mengacu pada Moleong (2017) yang mengungkapkan bahwa, sampel bertujuan mempunyai ciri-ciri salah satunya pemilihan berakhir jika sudah terjadi pengulangan. Jumlah sampel ditentukan berdasarkan pertimbangan informasi yang diperlukan. Jika tidak ada lagi informasi yang dapat dijaring, maka penarikan sampel pun sudah dapat diakhiri. Jadi, jika sudah terjadi pengulangan informasi, maka penarikan sampel sudah harus dihentikan.

Informan penelitian ini mengambil tujuh informan bukan delapan atau sembilan, karena tujuh informan sudah dianggap mencapai kejenuhan data. Seperti telah dikemukakan Sugiyono (2008) bahwa, jumlah sampel itu dihentikan, manakalanya datanya sudah jenuh. Dari berbagai informan, baik yang baru dan yang lama tidak memberikan data baru lagi. Berdasarkan penjelasan ini maka penelitian berhenti pada tujuh informan. Tujuh informan penelitian ini antara lain: dua orang yang tinggal disekitar taman syariah, tiga orang yang sering berkunjung ke taman syariah, dan dua orang tokoh masyarakat yang tinggal dekat dengan taman syariah.

Teknik pengumpulan data yang digunakan dalam penelitian ini adalah sebagai berikut:

1. Wawancara Mendalam

Wawancara Mendalam. Menurut Estenberg wawancara adalah pertemuan dua orang untuk bertukar informasi dan ide melalui tanya jawab, sehingga dapat dikonstruksikan makna dalam suatu topik tertentu.

2. Observasi

Observasi deskriptif ini peneliti melakukan penjelajahan umum, dan menyeluruh, melakukan deskripsi terhadap semua yang dilihat, didengar dan dirasakan. 


\section{Dokumentasi.}

Dokumen merupakan catatan peristiwa yang sudah berlalu. Dokumen bisa berbentuk tulisan, gambar, atau karya-karya monumental dari seseorang (Sugiyono, 2008).

Analisis data dilakukan pada saat pengumpulan data berlangsung, dan setelah selesai pengumpulan data dalam periode tertentu. Adapun komponen didalam analisis data diantaranya sebagai berikut (Sugiyono, 2008).

1. Data Reduction (Reduksi Data): Mereduksi data berarti merangkum, memilih hal-hal yang pokok, memfokuskan pada hal-hal yang penting, dicari tema dan polanya.

2. Data Display (Penyajian data). Penelitian kualitatif, penyajian data bisa dilakukan dalam uraian singkat, bagan, hubungan antar kategori, flowchart dan sejenisnya.

3. Conclusion Drawing / Verification (Penarikan Kesimpulan dan verifikasi) Kesimpulan awal yang dikemukakan masih bersifat sementara, dan akan berubah bila tidak ditemukan bukti-bukti yang kuat yang mendukung pada tahap pengumpulan data berikutnya.

\section{HASIL PENELITIAN}

\subsection{Sejarah Taman Syariah}

Taman syariah awalnya hanya lahan kosong tempat tumpukan sampah dan dibangun pada tahun 2016 untuk memberikan tempat rekreasi barn bagi masyarakat kota pare-pare yang ingin sejenak beristirahat untuk menunggu waktu sholat yang karena letaknya bersebelahan dengan mesjid. Taman syariah letaknya di kecamatan ujung merupakan wujud pembagunan keummatan sebagai Parepare kota santri yang mencerminkan hukum Islam. Taman ini memiliki batasan aktivitas bagi para pengunjung untuk tidak melakukan prilaku menyimpang. Aktivitas yang dibenarkan masyarakat misalnya dengan membaca al-qu'ran sedangkan yang dilarang seperti berpacaran atau mendekati zina. Perkembangannya masyarakat tidak melihat taman sebagai taman yang identik dengan ajaran agama Islam yang tercermin aktivitas yang melanggar ajaran namun beberapa masyarakat melihat taman hanya sebuah ruang publik yang semua orang dapat melakukan aktivitas yang mereka senangi terlepas dari hukum Islam, sehingga hadirlah dekonstruksi tentang nama taman yang hanya sebatas nama. Sampai saat ini taman difungsikan remaja untuk berpacaran.

\subsection{Persepsi Masyarakat Terhadap Remaja Berpacaran di Taman Syariah}

Hampir setiap harinya taman ditempati untuk berpacaran dikarenakan kurangnya pengawasan. Perilaku berpacaran remaja secara garis besar memiliki dua persepsi dal am masyarakat yaitu persepsi positif dan juga persepsi negatif. Persepsi positif yaitu masyarakat memandang perilaku pacaran di taman syariah bukanlah suatu penyimpangan (konformis) karena dianggap hal yang 
wajar saja ketika masih pada duduk berduaan, berpegangan tangan, sedangkan persepsi negatif yaitu masyarakat memandang perilaku pacaran remaja merupakan perilaku yang menyimpang (deviant) karena dianggap perbuatan zina yang melanggar norma agama dan melanggar etika kesopanan masyarakat sehingga menggangu masyarakat. Namun semua masyarakat berpandangan sama memiliki persepsi negatif ketika berpacaran remaja telah masuk pada pengungkapan diri secara seksual dengan berciuman, berpelukan, serta melakukan hubungan seksual diluar nikah maka sudah dianggap perilaku menyimpang. Sehingga pacaran masih dalam kategori penyimpangan yang relatif berdasarkan frekuensi yang dilakukan oleh remaja, karena masih banyak yang mentolerir perilaku tersebut.

\subsection{Kontrol sosial masyarakat yang dilakukan di taman syariah terhadap remaja yang berpacaran} terdiri dari bentuk, proses dan sifat yang berbeda.

1. Bentuk kontrol sosial yang dilakukan mulai dari rumor atau gosip, teguran, hingga kontrol agama. Kontrol berupa rumor atau gosip dilakukan oleh masyarakat terhadap remaja yang berpacaran di taman tapi sifatnya laten tapi hanya berlaku pada remaja sekitar taman saja. Selanjutnya bentuk teguran, teguran yang diberikan secara langsung kepada remaja yang berpacaran sejauh ini belum dilakukan karena dianggap masih pada batas wajar, dan terakhir kontrol agama hanya dilakukan oleh pengurus mesjid kepada remaja yang berpacaran dengan pemberian siraman rohani dengan sistim jamaah tablig.

2. Proses kontrol yang dilakukan masyarakat terdiri dari dua proses internalisasi dan proses eksternalisasi. Proses internalisasi yaitu dari proses sosialisasi yang didapatkan melalui jemaah tablig yang diberikan oleh pengurus mesjid yang hampir setiap hari memberikan kunjungan ke jamaah yang ada di taman membuat remaja memiliki kontrol diri yang kuat sehingga tidak berpacaran di taman namun tidak semua remaja melakukan proses kontrol internalisasi dalam dirinya masing-masing, sedangkan proses eksternalisasi yang didapatkan melalui tindakan tidak resmi yang dilakukan seperti gosip oleh masyarakat kepada remaja tersebut tidak berdasarkan pada nilai norma agama.

3. Sifat kontrol masyarakat terhadap remaja yang menyimpang ada tiga yaitu preventif, refresif, dan kuratif. Kontrol sosial preventif yang dengan cara pemberian pemahaman agama oleh pengurus mesjid yang melakukan kunjungan setiap harinya kepada remaja yang ada di taman syariah. Kontrol sosial refresif tidak dilakukan kepada remaja yang ada di taman syariah karena dianggap masih pada batas wajarnya. Kontrol sosial kuratif pun juga tidak diberikan karena tidak dianggap perlu karena perilaku remaja yang berpacaran di 
taman masih pada batasan wajar.

Kontrol sosial terhadap perilaku menyimpang remaja yang berpacaran hanya akan dilakukan maksimal oleh masyarakat ketika gaya berpacaran remaja telah memasuki fase keintiman yang mengarah pada pengungkapan diri secara seksual. Namun dari pengawasannya sendiri tidak dapat ia lakukan secara penuh dan sejauh ini belum pernah ia dapatkan secara langsung remaja yang berpacaran yang telah pada fase tersebut. Sehingga hal inilah yang membuat melemahnya kontrol sosial sehingga perilaku remaja yang berpacaran di taman syariah yang sudah melanggar secara Islam masih saja diperbolehkan selama masih batasan wajar.

Kontrol sosial masyarakat terhadap remaja baik dari bentuk, proses, dan sifat kontrol yang dilakukan bisa dikatakan sangatlah lemah karena pengetahuan tentang taman syariah masih minim. Kelemahan kontrol inilah yang membuat remaja melakukan penyimpangan seperti dengan aktivitas pacaran yang di taman syariah. Sesuai dengan teori kontrol yang mengatakan bahwa penyimpangan merupakan hasil dari kekosongan kontrol atau pengendalian sosial, pandangan ini dibangun atas dasar pandangan bahwa setiap manusia cenderung untuk tidak patuh pada hukum atau memiliki dorongan untuk melanggar atau sebagai konsekuensi logis kegagalan seseorang mentaati hukum.

Proposisi teori Hirschi yang pertama, berbagai bentuk pengingkaran terhadap aturan-aturan sosial adalah akibat dari kegagalan mensosialisasi individu warga masyarakat untuk bertindak konform terhadap aturan atau tata tertib yang ada. kegagalan kelompok konvensional terhadap si penyimpang mengenai aktivitas yang seharusnya tidak dilakukan di taman syariah menjadikan individu melakukan berperilaku menyimpang yaitu dengan berpacaran di taman syariah. Proses mensosialisasikan individu hanya dilakukan oleh tokoh agama dan tidak dilakukan oleh masyarakat lainnya sehingga bisa dikatakan gagal karena sebagian besar masyarakat sekitar taman syariah memang tidaklah melarang remaja berpacaran di taman syariah jika masih pada batas wajar.

Proposisi yang kedua, penyimpangan dan bahkan kriminalitas atau perilaku kriminal, merupakan bukti kegagalan kelompok sosial konvesional untuk mengikat individu agar tetap konform: keluarga, sekolah atau institusi pendidikan dan kelompok dominan lainnya. Kelompok kovensional yakni keluarga justru tidak mengikat anaknya atau remaja dengan membiarkan remaja untuk melakukan perilaku menyimpang tersebut seperti berpacaran di taman syariah dengan pandangan sudah sewajarnya ketika remaja berpacaran dan taman syariah yang hanyalah ruang publik yang semua aktivitas dapat dilakukan disana. 
Proposisi yang ketiga, setiap individu seharusnya belajar untuk konform dan tidak melakukan tindakan menyimpang atau kriminal. Proses belajar untuk konform tidak dilakukan oleh semua remaja yang berada di taman yang meskipun sosialisasi yang diberikan masyarakat sebagai dalam mengontrol sering dilakukan mengenai aktivitas yang dilarang melalui kontrol agama, namun tidak semua mau menerima dan tetap melakukan perilaku menyimpang dengan berpacaran di taman syariah.

Proposisi yang keempat, kontrol internal lebih berpengaruh daripada kontrol eksternal. Kontrol sosial eksternal yang dilakukan masyarakat sangatlah lemah dapat dilihat dari pembiaran mengalami kekosongan kontrol eksternal dalam masyarakatnya terhadap remaja yang berpacaran sehingga memang perlu untuk kontrol internal. Kontrol internal sangatlah berpengaruh untuk mengendalikan diri remaja untuk tidak berperilaku menyimpang di taman syariah.

3.4. Melemahnya kontrol sosial diakibatkan karena beberapa kendala dan hambatan yang dihadapi oleh masyarakat dalam melakukan kontrol sosial.

1. Faktor pertama, kurangnya sosialisasi yang diakibatkan karena masyarakat yang ingin memberikan sosialisasi tidak memiliki rasa percaya diri dan adanya rasa takut.

2. Faktor kedua, kurangnya pengawasan dari pemerintah, masyarakat menganggap pemerintah tidak pernah melakukan pengawasan yang seharusnya taman syariah perlu diberi pengawasan karena masyarakat sendiri tidak mampu mengawasinya secara maksimal.

3. Faktor ketiga, beragamnya nilai dan norma yang ada, karena taman syariah berada di pusat kota yang dimana banyak suku dan agama dan beragam kelompok yang memiliki nilai dan norma tersendiri sehingga pacaran remaja sulit untuk dikontrol secara sudut pandang agama Islam melainkan dilihat dari statusnya sebagai ruang publik yang semua berhak melakukan aktivitasnya disana.

\section{KESIMPULAN DAN SARAN}

Persepsi positif yaitu memandang perilaku pacaran di taman syariah bukanlah suatu penyimpangan (konformis), sedangkan persepsi negatif yaitu memandang perilaku pacaran remaja merupakan perilaku yang menyimpang (deviant), semua masyarakat berpandangan sama memiliki persepsi negatif ketika berpacaran remaja telah masuk pada pengungkapan diri secara seksual dengan berciuman, berpelukan, serta melakukan hubungan seksual diluar nikah maka sudah dianggap perilaku menyimpang.

Kontrol sosial masyarakat yang dilakukan di taman syariah terhadap remaja dari bentuk, proses dan sifat yang kurang maksimal. Kontrol sosial masyarakat hanya akan dilakukan secara maksimal ketika 
gaya berpacaran remaja telah memasuki fase keintiman yang mengarah pada pengungkapan diri secara seksual. Kontrol diri lebih berperan penting dalam mengontrol dibanding kontrol eksternal.

Melemahnya kontrol sosial diakibatkan karena beberapa kendala dan hambatan yang dihadapi oleh masyarakat dalam melakukan kontrol sosial.

1. Faktor pertama, kurangnya sosialisasi yang diakibatkan karena masyarakat yang ingin memberikan sosialisasi tidak memiliki rasa percaya diri dan adanya rasa takut.

2. Faktor kedua, kurangnya pengawasan dari pemerintah, masyarakat menganggap pemerintah tidak pernah melakukan pengawasan yang seharusnya tempat itu perlu diberi pengawasan karena masyarakat sendiri tidak mampu mengawasinya.

Faktor ketiga, beragamnya nilai dan norma yang ada, karena taman syariah berada di pusat kota yang dimana banyak suku dan agama dan beragam kelompok yang memiliki nilai dan norma tersendiri sehingga pacaran sulit untuk dikontrol secara sudut pandang agama Islam melainkan dilihat dari statusnya sebagai ruang publik yang semua berhak melakukan aktivitasnya disana.

\section{DAFTAR PUSTAKA}

Abercrombie, Nicholas, et al. (2010). Kamus Sosiologi. Diterjemahkan dari The Penguin Dictionary of Sociology, oleh Desi Noviyani, Eka Adinugraha, Rh. Widada. Yogyakarta: Pustaka Pelajar.

Alias, M, et al. (2013). Kontrol Sosial Tokoh Masyarakat (Ustad) dalam Mengatasi Penyimpangan Perilaku Remaja di Desa Limbung Kecamatan Sungai Raya Kabupaten Kubu Raya. Jurnal Tesis PMIS-UNTAN-PSS- 2013, 1-3.

Evita, Cecilia. (2007). Huhungan Antara Perilaku Menonton Film Percintaan Dengan Sikap Remaja Terhadap Perilaku Pacaran (Kasus Di Jakarta Timur: Sekolah Lanjutan Tingkat Pertama Negeri 99, Pulomas; Sekolah Menengah Atas Negeri 36, Rawamangun; dan Fakultas Ekonomi Universitas Negeri Jakarta, Rawamangun) [Skripsi]. Bogor: Institut Pertanian Bogor.

Hutami, Anisa Nurhesti. (2016). Pengaruh Persepsi Merck, Persepsi Harga, dan Persepsi Iklan TV Terhadap Minat Beli Kopi Siap Minum. Bogor: Institut Pertanian Bogor.

Jamal.(2017). Lengkap dengan Perpustakaan, Ini/ah Taman Syariah Pertama di Kota Parepare Sulawesi Selatan. https://www.gomuslim.co.id/read/news/2017/01/30/3043/lengkap-denganperpustakaan-inilah-taman-syariah-pertama-di-kota-parepare-sulawesi- selatan.html. Diakses tanggal, 27 Desember 2019.

Jamaluddin, Adon Nasrullah. (2016). Dasar-dasar Patologi Sosial. Bandung: CV Pustaka Setia.

Jannah, Miftahul, et al. (2015). Kajian Konsep Islam berdasarkan Al-Qur'an dan Hadist. Jurnal Budaya Islam El Harakah Vol 17 no.l tahun 2015.

Johnson, Doyle Paul. (1986). Teori Sosiologi Klasik dan Modem. Diterjemahkan dari Sosiological Theory Classical Founders and Contemporary Perspectives. Jakarta: PT Gramedia. (Penerjemah Robert M.Z. Lawang. Cetakan bahasa asli 1981)

Kartono, Kartini. (2011). Patologi Sosial II: Kenakalan Remaja. Jakarta: PT Raja Grafindo Persada. 
Khasanah, Khuswatun. (2018). Penyimpangan Perilaku Remaja dan Kontrol Sosial di Desa Menunggal Kecamatan Kedamean Kabupaten Gresik [Skripsi], Surabaya: Universitas Islam Negeri Sunan Ampel Surabaya.

Mantiri, Vive Vike. (2014). Perilaku Menyimpang di Kalangan Remaja di Kelurahan Pondang, Kecamatan Amurang Timur Kabupaten Minahasa Selatan. Jumal Acta Diurna, Volume III. No. 1,2.

Moleong, Lexy J.(2017). Metodologi Penelitian Kualitatif. Bandung: PT Remaja Rosdakarya

Mulyadi. (2017). Is lami dan Sejuk Beginilah Taman Syariah Parepare. https://makassar.tribunnews.com/amp/2017/01/29/islami-dan-sejuk-begini lah-taman-syariahparepare. Diakses tanggal, 4 Juli 2019.

Mulyadi. (2017). Taman Syariah Parepare Kerap Dijadikan Tempat Mesum di Mai am Hari. https://makassar.tribunnews.com/amp/2017/07/18/taman- $\quad$ syariah-parepare-kerap-dijadikantempat-mesum-di-malam-hari. Diakses tanggal, 4 Juli 2019.

Nasir, Muh. Ramadhan. (2018). Dampak Mobilitas Terhadap Kondisi Sosial Ekonomi Etnis Jcrwa di Kota Parepare [Skripsi], Makassar: Universitas Hasanuddin

Nikkitasari, Dessy Dwi. (2015). Konstruksi Sosial Tentang Pacaran Pada Mahasiswi Berhijab di Universitas Islam Surabaya. Jumal Universitas A irlangga, 4.

Noor, Juliansyah. (2014). Metodologi Penelitian: Skripsi, Tesis, Disertasi, dan Karya Ilmiah. Jakarta: Kencana Prenadamedia Group.

Pormawita, Lili. (2016). Persepsi Masyarakat Terhadap Perilaku Pacaran Remaja di Nagari Aur Durisurantih Kecamatan Sutera Pesisir Selatan [Artikel]. Sumatera Barat: Sekolah Tinggi Keguruan dan Ilmu Pendidikan.

Ritzer, George. (2014). Teori Sosiologi Dari Klasik Sampai Perkembangan Terakhir Posmodern. Yogyakarta: Pustaka Pelajar.

Setiadi, Elly M. \& Usman Kolip. (2011). Pengantar Sosiologi Pemahaman Fakta dan Gejala Permasalahan Sosial: Teori, Aplikasi, dan Pemecahannya. Jakarta: Pramedia Group.

Setiadi, Elly M. \& Usman Kolip. (2015). Pengantar Sosiologi Pemahaman Fakta dan Gejala Permasalahan Sosial: Teori, Aplikasi, dan Pemecahannya. Jakarta: Pramedia Group.

Siahaan, Jokie MS. (2009). Perilaku Menyimpang: Pendekatan Sosiologi. Jakarta: PT Indeks.

Siyoto, Sandu.(2017). Analisis Perilaku Pacaran pada Mahasiswa yang Mengalami Kehamilan Tidak Diinginkan di Kediri. Jumal Ilmiah Kesehatan STIKes Yarsi Mataram, Vol.7, No.1, 3.

Soekanto, Soerjono.(1997). Sosiologi Suatu Pengantar. Jakarta: PT Raja Grafindo Persada.

Soekanto, Soerjono.(2014). Sosiologi Suatu Pengantar. Jakarta: PT Raja Grafindo Persada.

Sugiyono.(2008). Memahami Penelitian Kualitatif. Bandung: CV Alfabeta 